\title{
PAJANAN PM2,5 TERHADAP KEJADIAN PNEUMONIA PADA BALITA DI KAWASAN PEMUKIMAN INDUSTRI DAN NON INDUSTRI KOTA PADANG TAHUN 2017
}

\author{
Febry Handiny ${ }^{1}$, Ema Hermawati ${ }^{2}$ \\ ${ }^{1}$ STIKes Alifah Padang, Jl. Khatib Sulaiman No. 52B Kel. Belanti. Padang \\ E-mail : handiny.febry@gmail.com \\ ${ }^{2}$,Departemen Kesehatan Lingkungan Fakultas Kesehatan Masyarakat Universitas Indonesia, \\ Gedung C Lantai 2 Kampus Baru UI Depok 16424, Indonesia \\ E-mail : ema.hermawati@ui.ac.id
}

\begin{abstract}
ABSTRAK
Pneumonia merupakan penyebab kematian utama anak-anak di seluruh dunia daripada penyakit-penyakit lainnya.. Period prevalence pneumonia pada balita di Indonesia adalah 18,5\% per mil. Dari tahun ke tahun terjadi peningkatan jumlah kasus pneumonia di Kota Padang. Inhalasi bahan kimia beracun seperti partikulat juga dapat menyebabkan inflamasi dan kerusakan jaringan di paru-paru sehingga diduga menjadi penyebab pneumonia. Penelitian ini bertujuan untuk menganalisis pajanan PM2,5 di udara dengan kejadian pneumonia pada balita yang tinggal di kawasan pemukiman industri dan dan non industri dan faktor risiko lainnya yang dapat menimbulkan pneumonia. Penelitian ini menggunakan desain case control. Sampel terdiri dari masingmasing 51 sampel untuk wilayah industri dan non industri berusia 12 bulan - 60 bulan. Hasil penelitian menunjukkan variabel yang berhubungan dengan pneumonia pada balita adalah ASI eksklusif dan pemberian vitamin A. Sedangkan konsentrasi PM2,5 di udara dan faktor pencemaran dalam ruangan tidak berhubungan dengan kejadian pneumonia pada balita. Kesimpulan didapatkan bahwa pneumonia pada balita dipengaruhi oleh PM2,5 di udara setelah dikontrol variabel letak dapur, ASI eksklusif vitamin A, status gizi, dan imunisasi campak. Di harapkan ibu balita meningkatkan kesadaran memberikan ASI eksklusif, memberikan vitamin dan menjaga kesehatan balita agar terhindar dari pneumonia.
\end{abstract}

Kata kunci : pneumonia; balita; pajanan $\mathrm{PM}_{2,5}$

\section{ABSTRACT}

Pneumonia is the leading cause of death among children worldwide than any diseases. More than 2 million children aged 1 to 5 years died of pneumonia each year across the region. The prevalence of children pneumonia in Indonesia is $18.5 \%$ per mile. From year to year there is an increasing number of cases of pneumonia in Padang, West Sumatera. Inhalation of toxic chemicals such as particulates can also cause inflammation and tissue damage in the lungs that suspected to be the cause of pneumonia. This study aims to analyze the relationship of $P M_{2.5}$ to incidence of children pneumonia living in industrial and non-industrial areas in Padang and other risk factors that lead to pneumonia. This study used case-control design. The sample consisted of 51 samples each for industrial and non-industrial areas aged within 12 months - 60 months. The results indicated that variables associated with pneumonia in children were exclusive breastfeeding and vitamin $A$. While the concentration of $P M_{2,5}$ and indoor air pollution factor were not associated to the incidence of pneumonia in children. In conclusion, the incidence of pneumonia in children is affected by the concentration of PM.5 after controlled by the location of the kitchen, exclusive breastfeeding, vitamin A, nutritional status, and measles immunization. It is recommended to improve the awareness of mothers to give exclusive breastfeeding, provide vitamin A and maintain the health of the children to avoid pneumonia.

Keywords : pneumonia; children; $P M_{2,5}$ exposure. 


\section{PENDAHULUAN}

Pneumonia adalah penyebab kematian terbanyak anak-anak daripada penyakit seperti AIDS (Acquired Immune Deficiency Syndrome), malaria dan campak. Lebih dari 2 juta anak-anak usia 1 sampai 5 tahun meninggal karena Pneumonia setiap tahunnya di seluruh wilayah. Lebih dari setengah kasus Pneumonia baru pertahun di dunia berpusat di lima negara yaitu 44\% dari anak-anak di dunia yang berusia $1-5$ tahun antara lain, India (43juta), Cina (21 juta), Pakistan (10 juta), Bangladesh, Indonesia serta Nigeria (masing-masing 6 juta) ${ }^{(1)}$.

Di Indonesia, period prevalence ISPA berdasarkan diagnosa tenaga kesehatan dan keluhan penduduk adalah $25,0 \%$. Lima provinsi dengan ISPA tertinggi adalah Nusa Tenggara Timur, Papua, Nusa Tenggara Barat, dan Jawa Timur. Pada Riskesdas 2007, Nusa Tenggara Timur merupakan provinsi tertinggi dengan ISPA. Insiden dan prevalensi pneumonia tahun 2013 sebesar $1,8 \%$ dan $4,5 \%$. Lima provinsi yang mempunyai insiden dan prevalensi pneumonia tertinggi untuk semua umur adalah Nusa Tenggara Timur, Papua, Sulawesi Tengah, Sulawesi Barat, dan Sulawesi Selatan. Terjadi juga kecenderungan yang meningkat untuk period prevalence pneumonia semua umur dari $2,1 \%$ menjadi $2,7 \%^{(2,3)}$.

Period prevalence pneumonia pada balita di Indonesia adalah $18,5 \%$ per mil. Balita pneumonia yang berobat hanya 1,6 per mil. Lima provinsi yang mempunyai insiden pneumonia balita tertinggi adalah Nusa Tenggara timur (38,5\%), Aceh (35,6\%), Bangka Belitung (34,8\%), Sulawesi Barat $(34,8 \%)$, dan Kalimantan Tengah $(32,7 \%)$. Insiden tertinggi pneumonia pada balita terdapat pada kelompok $12-23$ bulan $(21,7 \%)$. Pneumonia balita lebih banyak dialami pada kelompok penduduk dengan kuintil indeks kepemilikan terbawah $(27,4 \%)^{(3)}$.

Sumatera Barat menduduki posisi ke enam dari sepuluh besar penyakit ISPA tertinggi di Indonesia ${ }^{(3)}$ dengan Period prevalence ISPA sebesar 16,1 \% dan prevalensi Pneumonia sebesar 1,4\% dan Period prevalence pneumonia pada balita sebesar 3,4\%. Kota Padang, merupakan ibu kota dari Sumatera Barat dan merupakan kota terbesar di Sumatera Barat merupakan salah satu kota dengan angka ISPA pneumonia tertinggi dari tahun 2013 hingga 2015 menempati urutan pertama dalam sepuluh penyakit terbanyak di kota Padang ${ }^{(4,5,6)}$.

Kasus pneumonia di Kota Padang yang ditemukan dan ditangani beberapa tahun terakhir pada balita yang masing-masing diperoleh dari Dinas Kesehatan Kota Padang di tahun 2013 sebanyak 1.183 balita $(13,2 \%)$, tahun 2014 sebanyak 1.850 balita $(20,65)$, tahun 2015 sebanyak 2.486 balita $(30,25 \%)$. Dari tahun ke tahun terjadi peningkatan jumlah kasus pneumonia di Kota Padang ${ }^{(4,5,6)}$.

Penyebab pneumonia pada balita hingga mencapai paru-paru melalui inhalasi. Meskipun informasi patogenesis pneumonia pada anak terbatas, tetapi secara luas dipercaya bahwa bakteri patogen yang biasanya menyebabkan pneumonia sering berada di hidung dan mulut anak dan selanjutnya terinhalasi kedalam paru-paru dan menyebabkan infeksi. Inhalasi bahan kimia beracun seperti partikulat juga dapat menyebabkan inflamasi dan kerusakan jaringan di paru-paru sehingga menyebabkan pneumonia ${ }^{(7)}$.

Peningkatan pneumonia pada balita dalam beberapa tahun terakhir erat kaitannya dengan kondisi lingkungan seperti variasi iklim, kepadatan penduduk, kondisi bentang alam, dan kepadatan industri. Kota Padang termasuk salah satu kota industri dengan kepadatan lalu lintas yang cukup tinggi. Kegiatan industri berdampak negatif bagi kesehatan dan lingkungan, karena berperan dalam menyumbangkan emisi partikulat di udara dari tungku industri dan industri pengolahan.

Partikulat yang menjadi perhatian diantaranya $\mathrm{SO}_{2}, \mathrm{NO}_{2}, \mathrm{PM}_{10}$, dan $\mathrm{PM}_{2,5}$. $\mathrm{PM}_{2,5}$ dapat secara leluasa masuk ke dalam saluran pernapasan dan mengendap di alveoli. $\mathrm{PM}_{2,5}$ yang berasal dari kegiatan industri biasanya mengeluarkan berbagai material logam berat dan sulfur dioksida ${ }^{(8)}$. Sumber $\mathrm{PM}_{2,5}$ dari aktivitas manusia lebih banyak berpengaruh daripada sumber-sumber alami, terutama emisi dari aktivitas industri dan kendaraan di jalanan.

Masyarakat yang bermukim di kawasan industri merupakan yang paling berisiko terhadap pajanan $\mathrm{PM}_{2,5}$ di udara, seperti masyarakat di sekitar kawasan industri di kota Padang di Kecamatan Lubuk Kilangan. Kecamatan ini merupakan lokasi industri semen yang ada di Kota Padang dan merupakan salah satu penyumbang terbesar total emisi partikulat seperti $\mathrm{PM}_{2,5}$. Masyarakat yang sering terpajan atau bermukim di 
kawasan industri mengalami gangguan pernapasan sepereti batuk, asma, pneumonia dan penyempitan saluran pernapasan ${ }^{(8)}$. Bahaya $\mathrm{PM}_{2,5}$ terhadap gangguan paru, dimana kondisi organ pernapasan yang belum stabil dan rentan terhadap pencemaran udara luar ruangan diduga sebagai salah satu penyebab utama terjadinya pneumonia pada balita di Kota Padang.

\section{METODE PENELITIAN}

Penelitian ini menggunakan rancangan case control. Penelitian dilaksanakan di kawasan pemukiman industri dan non industri Kota Padang pada bulan Februari - Maret 2017. Populasi dalam penelitian ini adalah responden berusia $12-60$ bulan. Total sampel penelitian ini sebanyak 101 responden (masing-masing wilayah 51). Variabel yang diteliti dalam penelitian ini meliputi variabel dependen yaitu kejadian pneumonia, sedangkan variabel independen utama yang diteliti adalah konsentrasi $\mathrm{PM}_{2,5}$ di udara serta variabel lainnya yang terkait dengan pneumonia pada balita, faktor balita meliputi status gizi, riwayat berat lahir bayi, imunisasi campak, riwayat pemberian vitamin A, ASI eksklusif. Pengambilan sampel linkungan konsentrasi $\mathrm{PM}_{2,5}$ dilakukan dengan membuat ring di masing-masing wilayah penelitian. Kemudian terdapat faktor sosio-ekonomi dan faktor pencemaran dalam ruangan yang meliputi pemakaian obat nyamuk bakar, pemakaian bahan bakar masak letak dapur, lubang pembuangan asap dapur, kebiasaan merokok keluarga serumah, serta kebiasaan anggota keluarga membakar sampah. Penyajian data dengan distribusi frekuensi, analisis bivariat Chi Square dan multivariat menggunakan regresi logistik.

\section{HASIL PENELITIAN}

Konsentrasi $\mathrm{PM}_{2,5}$ kawasan pemukiman industri terendah berada di ring 3 dan ring 10 masingmasing sebesar $0,007 \mathrm{mg} / \mathrm{m}^{3}$. Sedangkan konsentrasi tertinggi berada di ring 6 yaitu sebesar $0,020 \mathrm{mg} / \mathrm{m}^{3}$ berlokasi di perumnas Indarung. Konsentrasi $\mathrm{PM}_{2,5}$ di kawasan industri diketahui tidak melewati Standar Baku Mutu yang ditetapkan oleh EPA yakni sebesar $0,035 \mathrm{mg} / \mathrm{m}^{3}$. Sedangkan konsentrasi $\mathrm{PM}_{2,5}$ kawasan pemukiman non industri terendah berada di ring 5 yaitu sebesar $0,007 \mathrm{mg} / \mathrm{m}^{3}$. Sedangkan konsentrasi tertinggi berada di ring 2 yaitu sebesar $0,032 \mathrm{mg} / \mathrm{m}^{3}$ berlokasi di SD surau Gadang

Tabel 1. Distribusi rata-rata konsentrasi $\mathrm{PM}_{2,5}$ di kawasan Pemukiman Industri dan Non Industri Tahun 2017

\begin{tabular}{lccccc}
\hline \multicolumn{1}{c}{$\begin{array}{c}\text { Variabel } \\
\text { PM 2,5 }\end{array}$} & Mean & $\begin{array}{c}\text { Standar } \\
\text { Deviasi }\end{array}$ & Median & Min - Max & NAB* \\
\hline Industri & 0,012 & 0,003 & 0,014 & $0,007-0,017$ & $0,035^{* *}$ \\
Non Industri & 0,016 & 0,008 & 0,016 & $0,007-0,032$ & \\
\hline
\end{tabular}

*NAB = Nlai Ambang Batas standar EPA (2008), **mg/m $\mathrm{m}^{3}$

Berdasarkan hasil pengukuran $\mathrm{PM}_{2,5}$ diketahui bahwa nilai rata-rata $\mathrm{PM}_{2,5}$ di kawasan pemukiman industri sebesar 0,012 dan kawasan non industri 0,016 dengan standar deviasi masingmasing sebesar 0,003 dan 0,008. Diketahui juga bahwa nilai rata-rata konsentrasi $\mathrm{PM}_{2,5}$ yang lebih tinggi berada di kawasan pemukiman non industri.

Sebaran peta menunjukkan bahwa subyek penelitian yang sakit terkonsentrasi di Kelurahan Padang Besi karena sesuai data puskesmas kawasan Kecamatan Lubuk Kilangan yang didapatkan bahwa sebagian besar subyek penelitian berada di kelurahan tersebut. Kemudian konsentrasi $\mathrm{PM}_{2,5}$ ditampilkan pada peta untuk memperoleh gambaran tingkat konsentrasi $\mathrm{PM}_{2,5}$ berdasarkan radius dari sumber pencemaran. Pengelompokkan tersebut antara lain rendah $(0,007$
$-0,015)$, dan tinggi $(0,015-0,032)$ menggunakan metode dispersi secara spasial.

Sebaran peta menunjukkan bahwa subyek penelitian yang sakit banyak ditemukan di Kelurahan Surau Gadang. Di kelurahan tersebut juga terdapat konsentrasi $\mathrm{PM}_{2,5}$ level tinggi $(0,015$ - 0,032). Beberapa subyek penelitian terlihat keluar dari kawasan penelitian, hal ini dikarenakan subyek penelitian berobat ke kawasan puskesmas penelitian sehingga peneliti memasukkan sebagai bagian dari subyek penelitian.

Penegakkan diagnosa pneumonia pada balita usia $12-60$ bulan ditentukan dengan hasil didapatkan dari data puskesmas kawasan penelitian, kemudian di validasi dengan melakukan pengecekan langsung ke rumah subyek penelitian. hasil yang didapatkan dapat dilihat di tabel 5.5. 
Distribusi frekuensi variabel penyakit pneumonia di kawasan pemukiman industri, balita yang menderita penyakit pneumonia sebesar $68,6 \%$ dan yang tidak menderita pneumonia sebesar 31,4\%. Sedangkan di kawasan pemukiman non industri, balita yang mengalami pneumonia sebesar 52,9\% dan yang tidak menderita pneumonia sebesar 47,1\%. Dengan demikian dapat diketahui bahwa pneumonia pada balita banyak ditemukan di kawasan pemukiman industri.

Karakteristik Ibu Balita di kawasan pemukiman industri menunjukkan retang umur ibu presentase tertinggi di usia 20 - 35 tahun sebesar $72,5 \%$ dimana usia tersebut termasuk dalam kurun reproduksi sehat. Dari 51 ibu balita di kawasan pemukiman industri, sebesar $40 \%$ berpendidikan tamat SMA, dan tamat perguruan tinggi hanya 13,7\%. Pekerjaan Ibu di kawasan ini sebagian besar beraktivitas sebagai ibu rumah tangga yaitu $88,2 \%$. Sebesar $64,7 \%$ penghasilan keluarga balita berada diatas UMK Kota Padang yaitu lebih dari Rp. 1.800.725,--

Sedangkan pada tabel kawasan pemukiman non industri menunjukkan rentang sebaran umur ibu balita, persentase tertinggi berada pada kategori rentang 20 - 35 tahun sebesar 92,2\% dimana usia tersebut termasuk dalam kurun reproduksi sehat. Dari 51 ibu balita di Kecamatan Nanggalo, sebesar $56,9 \%$ berpendidikan tamat SMA, sedangkan yang paling sedikit tamat SMP dan tamat perguruan tinggi hanya 35,3\%. Pekerjaan Ibu di Kecamatan Nanggalo sebagian besar beraktivitas sebagai ibu rumah tangga yaitu 86,3\% dan sebesar 72,5\% penghasilan keluarga balita berada kurang dari UMK Kota Padang yaitu lebih dari Rp. 1.800.725,--

Karateristik ibu balita di dua kawasan penelitian mempunyai karakteristik yang sama, dimana rentang usia ibu berada di rentang usia subur, sebagian besar berpendidikan SMA dengan aktivitas sehari-hari sebagai ibu rumah tangga dan tingkat pendapatan berada di atas UMK Kota Padang.

Kawasan pemukiman industri diketahui rentang usia balita, persentase tertinggi pada kategori batita (12-36 bulan) sebesar 64,7\% dengan berat badan lahir normal dengan presentase sebesar 98\%. Status gizi balita dalam keadaan gizi baik sebesar 90,2\% serta telah melakukan imunisasi campak sebesar $82,4 \%$ dengan riwayat pemberian vitamin A pada balita sebesar $94,1 \%$ dan balita yang ASI Eksklusif sebesar 52,9\%.
Sedangkan pada pemukiman non industri diketahui rentang usia balita, persentase tertinggi pada kategori batita (12-36 bulan) sebesar 74,5\% dengan berat badan lahir normal dengan presentase 98\%. Status gizi balita dalam keadaan gizi baik sebesar $96,1 \%$ serta telah melakukan imunisasi campak sebesar $88,2 \%$ dengan riwayat pemberian vitamin A pada balita sebesar 90,2\% dan balita yang diberikan ASI Eksklusif sebesar 80,4\%.

Dengan demikian dapat diketahui bahwa sebagian besar subyek penelitian lahir dengan berat lahir normal, dan berada dalam status gizi baik. Subyek penelitian juga telah melakukan imunisasi campak dan diberikan vitamin A. Namun ibu balita di kawasan pemukiman industri hanya sebagian yang melakukan ASI esklusif, hal ini terlihat dari presentasi ibu yang melakukan ASI ekslusif masih rendah, hanya sebesar 52,9\%.

Berdasarkan faktor penecemaran udara dalam ruangan diketahui bahwa sebagian besar subyek penelitian yaitu 72,5\% tidak menggunakan obat nyamuk. Kemudian 96,1\% subyek penelitian menggunakan jenis bahan bakar masak yang tidak menghasilkan asap pembakaran. Sedangkan untuk variabel letak dapur, hampir seluruh subyek penelitian mempunyai dapur yang tidak terpisah dari rumah yaitu sebesar $94,1 \%$ dan sebesar $56,9 \%$ subyek penelitian mempunyai lubang lubang pengasapan dapur. Sebesar 82,4 \% subyek penelitian mempunyai anggota keluarga responden merokok dan variabel sebesar $66,7 \%$ subyek penelitian tidak melakukan pembakaran sampah disekitar rumah.

Pada pemukiman pemukiman non industri, sebagian besar subyek penelitian tidak menggunakan obat nyamuk dengan presentase $68,6 \%$ dan $88,2 \%$ responden penelitian menggunakan jenis bahan bakar masak yang tidak menghasilkan asap pembakaran. Sedangkan untuk variabel letak dapur hampir semua subyek penelitian mempunyai dapur tidak terpisah dari rumah sebesar $98 \%$ dan sebesar $51 \%$ subyek penelitian mempunyai lubang pengasapan dapur. Sebagian besar anggota keluarga responden tidak merokok yaitu 70,6\% dan 80,4\% subyek penelitian tidak melakukan pembakaran sampah disekitar rumah.

Berikut merupakan hasil analisis bivariat dari variabel $\mathrm{PM}_{2,5}$, faktor balita, faktor sosioekonomi dan faktor pencemaran dalam ruangan. 
Tabel 1. Analisis Bivariat Pajanan $\mathrm{PM}_{2,5}$ Terhadap Pneumonia pada Balita di Kawasan Pemukiman Industri dan Non Industri

\begin{tabular}{lcccccc}
\hline \multirow{2}{*}{ Variabel PM 2,5 } & \multicolumn{2}{c}{ Kasus } & \multicolumn{2}{c}{ Kontrol } & \multirow{2}{*}{-value } & \multirow{2}{*}{ OR (95\% } \\
\cline { 2 - 5 } & $\mathbf{n}$ & $\mathbf{\%}$ & $\mathbf{n}$ & $\mathbf{\%}$ & \\
\cline { 1 - 2 } Industri & & & & & & \\
$\quad$ Tinggi & 11 & 68,8 & 5 & 31,3 & 1,000 & $1,008(0,282$ \\
$\quad$ Rendah & 24 & 68,6 & 11 & 31,4 & & $-3,610)$ \\
\hline Non Industri & & & & & & \\
$\quad$ Tinggi & 9 & 45,0 & 11 & 55,0 & \multirow{2}{*}{1,000} & $0,873(0,283$ \\
$\quad$ Rendah & 15 & 48,4 & 16 & 51,6 & & $-2,696)$ \\
\hline
\end{tabular}

Berdasarkan hasil uji statistik diketahui bahwa variabel konsentrasi $\mathrm{PM}_{2,5}$ dengan penyakit pneumonia pada balita di kawasan pemukiman industri menunjukkan tidak ada hubungan yang bermakna dengan $p$ value 1,000 ( $p$-value $>0,05$ ). Hasil analisis hubungan antara pajanan $\mathrm{PM}_{2,5}$ dengan pneumonia pada balita di pemukiman non industri diperoleh $p$-value 1,000 ( $p$-value $>0,05$ ) maka dapat disimpulkan tidak ada hubungan yang bermakna antara pajanan $\mathrm{PM}_{2,5}$ dengan kejadian pneumonia pada balita.

Berdasarkan hasil uji statistik di kawasan pemukiman industri diketahui bahwa variabel status gizi dengan penyakit pneumonia menunjukkan tidak ada hubungan yang bermakna dengan $p$ value 1,000 ( $p$-value $>0,05)$. Kemudian variabel ASI Eksklusif terhadap penyakit pneumonia menunjukkan tidak ada hubungan yang bermakna dengan $p$ value 0,557 ( $\mathrm{p}$-value $>0,05$ ). Variabel imunisasi campak terhadap penyakit pneumonia menunjukkan tidak ada hubungan yang bermakna dengan $p$ value 0,436 ( $p$-value $>0,05$ ). Kemudian pada variabel pemberian vitamin A terhadap penyakit pneumonia menunjukkan tidak ada hubungan yang bermakna dengan $p$-value 0,543 ( $p$-value $>0,05$ ). Hasil uji statistik yang dilakukan pada variabel berat badan lahir terhadap penyakit pneumonia menunjukkan tidak ada hubungan yang bermakna dengan $p$ value 0,314 ( $p$ value $>0,05$ ).

Kemudian pada bagian kawasan pemukiman non industri, diketahui bahwa variabel status gizi dengan penyakit pneumonia menunjukkan tidak ada hubungan yang bermakna dengan $p$ value 0,216 ( $p$-value > 0,05). Apabila dilihat dari nilai OR menunjukkan variabel status gizi tidak berisiko terhadap pneumonia dengan tingkat kepercayaan $95 \%$.

Hasil uji statistik yang dilakukan pada variabel ASI Eksklusif terhadap penyakit pneumonia menunjukkan terdapat hubungan yang bermakna dengan $p$ value 0,033 ( $p$-value $<0,05$ ). Adapun nilai OR menunjukkan bahwa balita yang tidak diberikan ASI ekslusif mempunyai risiko 6,25 kali mengalami pneumonia dibandingkan dengan balita yang diberikan ASI eksklusif

Kemudian pada variabel status imunisasi campak terhadap penyakit pneumonia pada balita menunjukkan tidak ada hubungan yang bermakna dengan $p$ value 1,000 ( $p$-value $>0,05$ ). Variabel pemberian vitamin A terhadap penyakit pneumonia menunjukkan adanya hubungan yang bermakna dengan $p$ value 0,018 ( $p$-value $<0,05$ ). Hasil uji statistik yang dilakukan pada variabel berat badan lahir terhadap penyakit pneumonia menunjukkan tidak ada hubungan yang bermakna dengan $p$ value $1,000$ ( $p$-value $>0,05)$.

Dapat disimpulkan bahwa faktor balita tidak mempunyai hubungan yang bermakna terhadap kejadian pneumonia pada balita di kawasan pemukiman industri, sedangkan faktor balita pada variabel ASI eksklusif dan pemberian vitamin A mempunyai hubungan yang bermakna terhadap kejadian pneumonia pada balita di kawasan pemukiman non industri.

Berdasarkan hasil uji statistik yang dilakukan dua kawasan pemukiman industri dan non industri diketahui tidak ada hubungan yang bermakna dengan $p$ value 1,000 dan 0,567 ( $p$-value $>0,05$ ). Dapat disimpulkan bahwa faktor sosioekonomi keluarga tidak mempunyai hubungan yang bermakna terhadap kejadian pneumonia pada balita di kawasan pemukiman industri maupun non industri. 
Tabel 2. Analisis Bivariat Karakteristik Balita Terhadap Pneumonia pada Balita di Kawasan Pemukiman Industri dan Non Industri

\begin{tabular}{|c|c|c|c|c|c|c|}
\hline \multirow{2}{*}{ Faktor Balita } & \multicolumn{2}{|c|}{ Kasus } & \multicolumn{2}{|c|}{ Kontrol } & \multirow{2}{*}{ p-value } & \multirow{2}{*}{ OR $(95 \%$ CI $)$} \\
\hline & $\mathbf{n}$ & $\%$ & $\mathbf{n}$ & $\%$ & & \\
\hline \multicolumn{7}{|l|}{ Industri } \\
\hline \multicolumn{7}{|l|}{ Status Gizi } \\
\hline Gizi Kurang & 4 & 80,0 & 1 & 20,0 & \multirow{2}{*}{1,000} & \multirow{2}{*}{$\begin{array}{c}1,935(0,199- \\
18,854)\end{array}$} \\
\hline Gizi Baik & 31 & 67,4 & 15 & 32,6 & & \\
\hline \multicolumn{7}{|l|}{ ASI Eksklusif } \\
\hline Tidak & 15 & 62,5 & 9 & 37,5 & \multirow[t]{2}{*}{0,557} & \multirow{2}{*}{$0,583(0,177-1,924)$} \\
\hline $\mathrm{Ya}$ & 20 & 74,1 & 7 & 25,9 & & \\
\hline \multicolumn{7}{|c|}{ Imunisasi Campak } \\
\hline Tidak & 5 & 55,6 & 4 & 44,4 & \multirow[t]{2}{*}{0,436} & \multirow{2}{*}{$0,500(0,114-2,186)$} \\
\hline $\mathrm{Ya}$ & 30 & 71,4 & 12 & 28,6 & & \\
\hline \multicolumn{7}{|l|}{ Pemberian Vit. A } \\
\hline Tidak & 3 & 100 & 0 & 0 & \multirow[t]{2}{*}{0,543} & \multirow[b]{2}{*}{-} \\
\hline $\mathrm{Ya}$ & 32 & 66,7 & 16 & 33,3 & & \\
\hline \multicolumn{7}{|l|}{ Berat Bayi Lahir } \\
\hline BBLR & 0 & 0 & 1 & 100 & \multirow[t]{2}{*}{0,314} & \multirow[b]{2}{*}{-} \\
\hline Normal & 35 & 70,0 & 15 & 30,0 & & \\
\hline \multicolumn{7}{|l|}{ Non Industri } \\
\hline \multicolumn{7}{|l|}{ Status Gizi } \\
\hline Gizi Kurang & 2 & 100 & 0 & 0,0 & \multirow[t]{2}{*}{0,216} & \\
\hline Gizi Baik & 22 & 44,9 & 27 & 55,1 & & \\
\hline \multicolumn{7}{|l|}{ ASI Eksklusif } \\
\hline Tidak & 8 & 80,0 & 2 & 20,0 & \multirow[t]{2}{*}{$\mathbf{0 , 0 3 3}$} & $6250(1175-33258)$ \\
\hline $\mathrm{Ya}$ & 16 & 39,0 & 25 & 61,0 & & $0,250(1,1 / 5-35,258)$ \\
\hline \multicolumn{7}{|l|}{ Imunisasi Campak } \\
\hline Tidak & 3 & 50,0 & 3 & 50,0 & \multirow[t]{2}{*}{1,000} & \multirow{2}{*}{$1,143(0,208-6,282)$} \\
\hline Ya & 21 & 46,7 & 24 & 53,3 & & \\
\hline Pemberian Vit. A & & & & & & \\
\hline Tidak & 5 & 100 & 0 & 0,0 & 0,018 & \\
\hline Ya & 19 & 41,3 & 27 & 58,7 & & $=$ \\
\hline Berat Bayi Lahir & & & & & & \\
\hline BBLR & 0 & 0,0 & 1 & 100 & 1,000 & \\
\hline Normal & 24 & 48,0 & 26 & 52,0 & & \\
\hline
\end{tabular}

Tabel 3. Analisis Bivariat Status Sosio-ekonomi Terhadap Pneumonia pada Balita di Kawasan Pemukiman Industri dan Non Industri

\begin{tabular}{|c|c|c|c|c|c|c|}
\hline \multirow{2}{*}{ Sosio-ekonomi } & \multicolumn{2}{|c|}{ Kasus } & \multicolumn{2}{|c|}{ Kontrol } & \multirow{2}{*}{$p$-value } & \multirow{2}{*}{ OR $(95 \%$ CI $)$} \\
\hline & $\mathbf{n}$ & $\%$ & $\mathbf{n}$ & $\%$ & & \\
\hline \multicolumn{7}{|l|}{ Industri } \\
\hline$<\mathrm{UMK}$ & 12 & 66,7 & 6 & 33,3 & 1,000 & 0,870 \\
\hline$>\mathrm{UMK}$ & 23 & 69,7 & 10 & 30,3 & & $(0,254-2,973)$ \\
\hline
\end{tabular}

Non Industri 


\begin{tabular}{ccccccc}
$<$ UMK & 8 & 57,1 & 6 & 42,9 & 0,567 & 1,750 \\
$>$ UMK & 16 & 43,2 & 21 & 56,8 & & $(0,505-6,062)$ \\
\hline
\end{tabular}

Berdasarkan hasil uji statistik yang dilakukan dua kawasan pemukiman industri dan non industri diketahui tidak ada hubungan yang bermakna dengan $p$ value 1,000 dan 0,567 ( $p$-value > 0,05). Dapat disimpulkan bahwa faktor sosio-ekonomi keluarga tidak mempunyai hubungan yang bermakna terhadap kejadian pneumonia pada balita di kawasan pemukiman industri maupun non industri.

Tabel 4. Model Akhir Analisis Pajanan $\mathrm{PM}_{2,5}$ Terhadap Pneumonia pada Balita di Kawasan Pemukiman Industri Tahun 2017

\begin{tabular}{lcccc}
\hline \multicolumn{1}{c}{ Variabel } & B & Nilai P & OR & 95\% CI \\
\hline Industri & $-0,375$ & 0,599 & 0,687 & $0,170-2,780$ \\
$\quad$ PM 2,5 & 22,176 & 0,999 & 4275453065 & - \\
Pemberian Vitamin A & 2,062 & 0,182 & 7,861 & $0,381-162,033$ \\
$\quad$ Status Gizi & $-2,189$ & 0,068 & 0,112 & $0,011-1,180$ \\
$\quad$ Imuni sasi Campak & $-22,637$ & 0,999 & - & - \\
$\quad$ Konstanta & 0,253 & 0,686 & 1,288 & $0,378-4,389$ \\
\hline Non Industri & $-21,830$ & 1,000 & - & - \\
$\quad$ PM2,5 & 1,965 & 0,999 & 0,025 & $1,284-39,669$ \\
Letak dapur & $-1,592$ & 0,092 & 0,204 & - \\
$\quad$ ASI eksklusif & &
\end{tabular}

Pada pemodelan akhir di wilayah industri didapatkan variabel confounder yaitu pemberian vitamin A, status gizi, dan imunisasi campak. Berdasarkan hasil analisis multivariat dengan regresi logistik didapatkan OR untuk $\mathrm{PM}_{2,5}$ adalah $0,687$ (95\% CI : $0,170-2,780)$ yang berarti bahwa balita yang tinggal di kawasan pemukiman industri dengan konsentrasi $\mathrm{PM}_{2,5}$ tinggi mempunyai risiko untuk menderita pneumonia sebesar 0,687 kali dibandingkan balita yang tinggal di pemukiman industri dengan konsentrasi $\mathrm{PM}_{2,5}$ rendah setelah di kontrol oleh pemberian vitamin A, status gizi, dan imunisasi campak.

Sedangkan pada pemodelan akhir wilayah non industri didapatkan variabel confounder yaitu letak dapur dan ASI eksklusif. Berdasarkan hasil analisis multivariat dengan regresi logistik didapatkan OR PM2,5 adalah 1,288 (95\% CI : 0,378
$-4,389$ ) yang berarti bahwa balita yang tinggal di kawasan pemukiman non industri dengan

konsentrasi $\mathrm{PM}_{2,5}$ tinggi mempunyai risiko untuk mengalami pneumonia sebesar 1,288 kali dibandingkan dengan balita yang tinggal di konsentrasi $\mathrm{PM}_{2,5}$ rendah setelah di kontrol oleh letak dapur dan ASI eksklusif.

\section{PEMBAHASAN}

\section{Hubungan $\mathbf{P M}_{2,5}$ Terhadap Kejadian Pneumonia}

Anak-anak, terutama balita dan usia lanjut dalah kelompok yang sangat rentan terhadap pencemaran udara yang menyebabkan batuk, flu, bronkitis akut dan kronik, asma, pneumonia, emfisema paru, dan kanker paru merupakan manifestasi dari penyakit-penyakit saluran 
pernpasan akibat terpajan polusi udara yang cukup lama yang salah satunya adalah partikel debu ${ }^{(9)}$.

Konsentrasi $\mathrm{PM}_{2,5}$ di wilayah pemukiman industri dan non industri masih dibawah standar baku mutu kemungkinan disebabkan oleh infrastruktur dan pengendalian dampak lingkungan saat proses produksi oleh industri semen. Cerobong kiln dan coal mill pada industri telah dilengkap dengan electrotastic precipitator yang dapat menyerap emisis partikulat dengan efisiensi yang kuat.

Selain faktor tersebut, faktor alat ukur juga dapat mempengaruhi nilai konsetrasi. Peneliti menggunakan metode laser analyzer dengan alat Haz Dust EPAM 5000. Pengukuran dengan metode gravimetrik dapat memberikan hasil yang berbeda dengan metode laser analyzer. Hasil pengukuran dengan gravimetrik menghasilkan hingga $3-8$ kali nilai lebih besar dibandingkan pengukuran dengan metode laser analyzer ${ }^{(10)}$. Semua konsentrasi $\mathrm{PM}_{2,5}$ di wilayah pemukiman industri menunjukkan angka tidak lebih dari 20 $\mathrm{mg} / \mathrm{m}^{3}$.

Hasil penelitian menunjukkan bahwa tidak terdapat hubungan yang signifikan antara pajanan $\mathrm{PM}_{2,5}$ di udara dengan kejadian pneumonia pada balita di wilayah pemukiman industri dan non industri yaitu $p$-value masing-masing wilayah sebesar 0,166 dan 0,081 dimana kedua nilai tersebut menunjukkan bahwa $\mathrm{PM}_{2,5}$ tidak behubungan dengan kejadian pneumonia di wilayah pemukiman industri dan non industri.

\section{Hubungan Faktor Balita dengan Kejadian Pneumonia pada Balita}

a. Status Gizi

Diketahui bahwa gizi kurang akan menghambat reaksi imunologis dan berhubungan dengan tingginya prevalensi dan beratnya penyakit infeksi. Keadaan gizi buruk merupakan salah satu faktor risiko yang penting pada pneumonia. Berbagai penelitian yang pernah dilakukan terbukti bahwa status gizi buruk berhubungan dengan infeksi paru, sehinga anak dengan gizi buruk rentan terhadap penyakit pneumonia ${ }^{(1)}$.

Hasil Penelitian menunjukkan bahwa status gizi balita tidak mempunyai hubungan yang bermakna terhadap pneumonia pada balita baik di pemukiman industri ( $p$ value $=1,000$ ) maupun non industri ( $p$ value $=0,216)$. Status gizi tidak mempunyai hubungan yang signifikan pada penelitian ini disebabkan karena hampir seluruh balita berstatus gizi baik sehingga hasilnya tidak berpengaruh terhadap kejadian pneumonia pada balita.

Hasil ini sama dengan penelitian yang di lakukan oleh Rahmawati ${ }^{(12)}$ menjelaskan tidak terdapat hubungan yang bermakna antara status gizi dan kejadian pneumonia pada balita di wilayah kerja Puskesmas Natar, Lampung Selatan. Namun hasil ini berbeda dengan penelitian Sudirman yang menyatakan terdapat hubungan yang signifikan antara status gizi dan kejadian pneumonia pada balita dengan status gizi kurang mempunyai risiko 11,69 kali mengalami pneumonia daripada balita dengan status gizi baik ${ }^{(13)}$.

Beberapa penelitian menyatakan bahwa kekurangan gizi akan menurunkan kapasitas kekebalan untuk merespon infeksi pneumonia termasuk gangguan fungsi granulosit, penurunan fungsi komplemen dan menyebabkan kekurangan mikronutrien $^{(14)}$. Pemberian Nutrisi yang sesuai dengan pertumbuhan dan perkembangan balita dapat mencegah dan terhindar dari penyakit infeksi sehingga pertumbuhan dan perkembangan anak menjadi optimal.

b. Riwayat Berat Lahir Bayi

Berat badan lahir rendah mempunyai risiko kematian yang lebih besar dibandingkan dengan berat badan lahir normal, terutama pada bulan-bulan pertama kelahiran karena pembentukan zat anti kekebalan kurang sempurna sehingga lebih mudah terserang penyakit infeksi, terutama pneumonia dan penyakit saluran pernapasan lainnya ${ }^{(15)}$. Sejumlah teori menyatakan bahwa riwayat BBLR berhubungan dengan morbiditas dan mortalitas infeksi saluran pernapasan bawah. Studi kasus kontrol di Brazil dan Srilangka menunjukkan bahwa balita dengan BBLR mempunyai risiko 50\% lebih besar untuk terkena pneumonia dibandingkan dengan balita dengan berat lahir normal ${ }^{(16)}$. Peningkatan risiko morbiditas dan mortalitas pada balita BBLR kemungkinan disebabkan oleh rendahnya imunitas dan menurunnya fungsi paru. Hal tersebut diperparah dengan pola asupan gizi yang buruk. Balita BBLR yang tidak memperoleh asupan gizi yang adekuat saat usia bayi akan berisiko malnutrisi lajut hingga dewasa ${ }^{(17)}$.

Penelitian di wilayah pemukiman industri dan non industri menunjukkan bahwa status gizi balita tidak ada hubungan yang bermakna dengan pneumonia ( $p$-value $=0,314$ dan 1,000). Penelitian ini juga sejalan dengan penelitian yang dilakukan 
oleh Herman ${ }^{(18)}$ juga tidak menemukan adanya hubungan bermakna antara berat badan lahir dengan kejadian pneumonia $(\mathrm{OR}=1,9 ; 95 \% \mathrm{CI}=$ $0,7-4,9, p$ value $=0,175)$. Hal ini sejalan dengan penelitian James dalam Herman yang menyatakan bahwa balita dengan riwayat BBLR mengalami penyakit saluran pernapasan dan jumlahnya tidak lebih dari anak-anak dengan beratbadan lahir normal. Namun, James menyatakan bahwa balita dengan BBLR dan malnutrisi mengalami pneumonia 19 kali lebih tinggi, serta memerlukan perawatan di rumah sakit dibandingkan dengan balita normal ${ }^{(18)}$.

Hasil penelitian Rizikianti ${ }^{(17)}$ menyatakan bahwa proporsi pneumonia pada balita dengan riwayat BBLR $(12,5 \%)$ lebih rendah dibandingkan dengan balita normal $(15,5 \%)$. Pada penelitian tersebut, balita dengan riwayat normal memiliki risiko 1,25 kali lebih besar untuk menderita pneumonia dibandingkan dengan riwayat BBLR. Namun hasil penelitian tersebut tidak menunjukkan hubungan yang bermakna secara statistik sehingga dikatakan bahwa tidak ada perbedaan proporsi pneumonia antara balita BBLR dengan balita normal. Adanya hubungan yang tidak bermakna pada penelitian ini disebabkan hampir seluruh balita mempunyai riwayat berat lahir normal sehingga hasilnya tidak berpengaruh terhadap kejadian pneumonia pada balita.

\section{c. ASI Eksklusif}

Hasil penelitian di wilayah pemukiman industri menunjukkan bahwa ASI eksklusif tidak ada hubungan yg signifikan dengan kejadian pneumonia pada balita $(p$-value $=0,754)$. Namun hasil yang berbeda ditemukan di wilayah pemukiman non industri dimana ASI eksklusif menunjukkan hubungan yang signifikan ( $p$-value $=$ $0,033)$ dimana balita yang tidak diberikan ASI eksklusif mempunyai risiko 6,25 kali mengalami pneumonia dibandingkan dngan balita yang diberikan ASI eksklusif.

Hasil penelitian di wilayah pemukiman non industri ini dapat diterima karena ASI mengandung dua macam kekebalan, yaitu kekebalan non spesifik yang terdiri dan laktobasilus bifidus, lisozim, dan laktoperoksidase. Sedangkan kekebalan spesifik dalam ASI adalah sistem komplemen, seluler, dan terdapat 30 jenis imunoglobulin. Melalui rangsangan yang spesifik terhadap immunoglobulin A, akan terbentuk antibody yang spesifik terhadap berbagai macam jenis bakteri dan virus salah satunya Streptococcus pneumoniae $^{(19)}$.

Hasil penelitian lain yang dilakukan di Amerika Serikat oleh Chantry, didapatkan bayi yang diberikan ASI eksklusif selama $4-6$ bulan berisiko lebih besar untuk terkena pneumonia dibandingkan dengan bayi yang diberikan ASI eksklusif penuh selama 6 bulan $^{(20)}$.

\section{d. Imunisasi Campak}

Penyakit pneumonia dapat dicegah dengan imunisasi, diantaranya imunisasi campak ${ }^{(21)}$, anak yang belum pernah diimunisasi campak meningkatkan faktor risiko terjadinya kematian bayi dan balita akibat pneumonia. Bayi dan balita yang pernah terserang campak akan mendapatkan kekebalan alami terhadap pneumonia sebagai komplisi campak. Beberapa hasil penelitian menunjukkan bahwa pneumonia dapat dicegah dengan pemberian imunisasi campak dan pertusis $^{(22)}$

Hasil penelitian ini menunjukkan bahwa tidak terhadapat hubungan antara imunisasi campak dengan kejadian pneumonia pada balita di pemukiman industri $\quad(p$-value $=0,436)$ dan non industri $(p$-value $=1,000)$. Hubungan tidak bermakna antara imunisasi campak dan pneumonia disebabkan karena hampir seluruh subyek penelitian telah melakukan imunisasi campak (tabel 7). Hasil penelitian ini sejalan dengan hasil penelitian Boer $^{(21)}$ yang menunjukkan bahwa tidak terdapat hubungan yang bermaknsa antara imunisasi campak dengan kejadian pneumonia pada balita dengan $p$ value $=0,774$ dan $\mathrm{OR}=0,883$.

Penelitian yang dilakukan oleh Sumargono $^{(23)}$ di Jakarta, ditemukan bahwa balita yang tidak mendapatkan imunisasi lengkap mempunyai risiko yang lebih besar utnuk menderita pneumonia dibandingkan dengan balita yang mendapatkan imunisasi lengkap. Selain itu, balita yang tidak mendapatkan imunisasi campak mempunyai risiko kesakitan pneumonia 1,44 5,88 kali bila dibandingkan dengan balita dengan imunisasi campak.

Balita yang telah mendapatkan imunisasi campak diharapkan terhindar dari penyakit campak dan pneumonia merupakan komplikasi yang paling sering terjadi pada anak yang mengalami penyakit campak Oleh karena itu imunisai campak sangat penting untuk mencegah terjadinya pneumonia ${ }^{(24)}$. e. Pemberian Vitamin A 
Vitamin A berperan protektif dalam melawan infeksi dengan memelihara integritas epitel/fungsi barrier kekebalan tubuh dan mengatur pengembangan fungsi paru ${ }^{(25)}$. Kapsul vitamin A diberikan setahun dua kali pad abulan Februari dan Agustus, sejak anak berusia enam bulan. Kapsul merah (dosis $100.000 \mathrm{IU}$ ) diberikan untuk bayi berusia 6 - 11 bulan dan kapsu biru (dosis 200.000 IU) untuk anak berumur $12-59$ bulan.

Hasil pada penelitian ini ditemukan bahwa tidak terdapat hubungan antara pemberian vitamin A terhadap pneumonia pada balita di wilayah pemukiman industri ( $p$-value $=0,543)$. Hal ini terjadi kemungkinan manfaat vitamin A bukan pada pencegahan pneumonia, namun lebih ke pencegahan komplikasi lebih lanjut apabila balita menderita pneumonia. Hal ini sesuai dengan penelitian oleh Kartasasmita ${ }^{(20)}$ yang menyatakan bahwa tidak terdapat hubungan antara pemberian vitamin A dengan insiden atau beratnya pneumonia pada balita

Namun terdapat hubungan antara pemberian vitamin A dengan pneumonia di wilayah non industri ( $p$-value $=0,018$ ). Hasil penelitian yang dilakukan oleh Herman ${ }^{(18)}$ yang menyatakan terdapat hubungan yang bermakna antara riwayat pemberian vitamin A dengan kejadian pneumonia dimana balita yang yang tidak memiliki riwayat pemberian vitamin A mempunyai risiko 4,14 kali untuk menderita pneumonia dibandingkan dengan balita yang tidak mempunyai riwayat pemberian vitamin A. Vitamin A mempunyai berbagai manfaat diantaranya membantu penyesuian cahaya pada mata (buta senja), menjaga kesehatan kulit dan selaput lender pada organ pernapasan, meningkatkan sistem kekebalan tubuh dan fungsi lain yang mencegah komplikasi penyakit yang terjadi pada balita seperti campak dan diare.

\section{Hubungan Sosio-ekonomi Terhadap Kejadian Pneumonia pada Balita}

Hasil penelitian ini menunjukkan bahwa status sosio-ekonomi (pendapatan) keluarga dengan kejadian pneumonia tidak ada hubungan yang bermakna baik di wilayah pemukiman industri $(p$-value $=1,000)$ maupun di wilayah pemukiman non industri ( $p$-value $=0,567)$. Hubungan yang tidak signifikan terjadi kemungkinan disebabkan karena penetapan tinggi rendahnya pendapatan keluarga yang tidak tepat. Penghitungan pendapatan seharusnya diikuti dengan pengeluaran dan pemasukan keluarga sehingga diketahui daya beli untuk memanfaatkan fasilitas jaminan kesehatan khususnya untuk balita. Penelitian Sumiati ${ }^{(22)}$ menunjukkan hubungan yang bermakna antara sosial-ekonomi keluarga dengan kejadian pneumonia balita dimana balita yang berasal dari keluarga yang sosial ekonominya kurang berisiko 1,948 kali untuk mengalami pneumonia dibandingkan dengan balita yang berasal dari keluarga dengan sosial ekonomi yang cukup.

\section{Hubungan Faktor Pencemaran Udara dalam Ruangan Terhadap Kejadian Pneumonia pada Balita}

a. Pemakaian Obat Nyamuk Bakar

Menurut pengkajian epidemiologi oleh Koo dan Ho (1994) dalam Purwana ${ }^{(26)}$ menyatakan peran obat nyamuk bakar dalam menimbulkan gejala gangguan saluran pernapasan serta asap obat nyamuk sebagai sumber partikulat. Pentingnya obat nyamuk bakar dalam menimbulkan gangguan pernapasan karena kandungan bahan karsinogenik benz(a)anthracene dalam partikulat hasil bakaran.

Penggunaaan obat nyamuk bakar tidak dianjurkan karena penggunan 1 gulung obat nyamuk bakar sama dengan mengkonsumsi 75 137 batang rokok ${ }^{(27)}$. Asap yang dihasilkan dari obat nyamuk bakar mengandung carbonil compound (formaldehyde dan acetaldehyde) yang bersifat karsinogenik karena dapat menyebabkan iritasi pada saluran pernapasan pada jangka pendek dan asma, gangguan saluran pernapasan permanen pada balita dalam jangka panjang serta pyrethoids (d-alltehrin, esbiothrin, transfluthrin, dan metofluthrin) yang menyebabkan polusi. Asap yang dihasilkan dari sisa pembakaran tersebut dapat meningkatkan risiko 3 kali menglami gangguan saluran pernapasan pada balita terpajan dibandingkan dengan balita yang tidak terpajan ${ }^{(28)}$. Hasil penelitian ini menunjukkan pemakaian obat nyamuk tidak mempunyai hubungan yang bermakna terhadap kejadian pneumonia baik di pemukiman wilayah industri ( $p$ value 1,000) dimana keluarga balita yang tidak memakai obat nyamuk bakar mempunyai peluang 1,2 kali tidak mengalami pneumonia dibandingkan dengan keluarga yang keluarga yang memakai obat nyamuk bakar. Sedangkan pemukiman non industri ( $p$-value $=0,557)$ dimana keluarga balita yang tidak memakai obat nyamuk bakar mempunyai peluang 1,714 kali tidak mengalami pneumonia 
dibandingkan dengan keluarga yang keluarga yang memakai obat nyamuk bakar.

Tidak adanya hubungan yang bermakna antara pemakaian obat nyamuk bakar dengan pneumonia pada balita kemungkinan disebabkan karena subyek penelitian yang memakai obat nyamuk bakar berjumlah sedikit sehingga pengaruhnya terhadap penyakit tidak terlalu besar.

\section{b. Pemakaian Bahan Bakar Masak}

Asap yang berasal dari sisa pembakaran saat memasak dapat menimbulkan gangguan saluran pernapasan seperti infeksi saluran pernapasan akut dan chronic obstructive pulmonary disease (COPD) serta pneumonia ${ }^{(29)}$. Jenis bahan bakar yang digunakan untuk memasak sehari-hari mempunyai efek yang berbeda-beda terhadap kesehatan penghuni rumah. Hal ini dikaitkan dengan jenis polutan yang dihasilkan oleh masing-masing jenis bahan bakar tersebut.

Hasil penelitian menunjukkan bahwa pemakaian bahan bakar masak tidak mempunyai hubungan yang bermakna terhadap kejadian pneumonia pada balita baik di wilayah pemukiman industri $(p$-value $=1,000)$ maupun di wilayah pemukiman non industri ( $p$-value $=0,67)$.

Hal ini sesuai dengan penelitian Ellegard $^{(30)}$ yang menjelaskan bahwa jumlah partikulat yang dihasilkan kompor minyak tanah hanya sedikit. Efek yang ditimbulkan minyak tanah adalah dalam jangka panjang dan jika dibandingkan denan bahan bakar kayu untuk memasak, umumnya rendah. Namun penelitian Hananto $^{(31)}$ menyatakan bahwa terdapat hubungan yang bermakna bahan bakar memasak dengan kejadian pneumonia pada balita.

Dalam penelitian ini tidak adanya hubungan kemungkinan disebabkan oleh subyek penelitian yang menggunakan bahan bakar masak yang menimbulkan pencemaran dalam ruangan seperti kayu dan minyak tanah ditemukan sedikit sehingga bahan bakar masak tidak berhubungan dengan kejadian pneumonia pada balita.

c. Letak Dapur

Letak dapur dalam penelitian ini dikelompokkan menjadi dua, yaitu berdekatan dengan kamar tidur/tidak memisah dan memisah. Hal ini diasumsikan bahwa letak dapur yang tidak memisah/berada satu ruangan dengan kamar balita dapat memperberat terjadinya pencemaran dalam ruangan. Hasil penelitian ditemukan bahwa letak dapur tidak mempunyai hubungan yang bermakna terhadap kejadian pneumonia pada balita baik di wilayah pemukiman indutri $(p$-value $=0,543)$ maupun di pemukiman non industri ( $p$-value $=$ 0,471).

Hasil penelitian ini sejalan dengan penelitian yang dilakukan oleh Hananto $(2004,28)$ dimana letak dapur tidak ada hubungan yang bermakna dengan pneumonia. Namun hasil ini berbeda dengan penelitian Juliastuti ${ }^{(32)}$ yang menyatakan terdapat hubungan yang bermakna dengan kejadian pneumonia.

\section{d. Lubang Pengasapan Dapur}

Lubang pengasapan dapur mempunyai fungsi sebagai saran penyaluran udara didalam dapur ke udara luar. Sama halnya dengan ventilasi, lubang perngasapan dapur dijadikan sebagai saluran pembuangan hasil aktivitas memasak di dapur, dengan demikian diharapkan partikulat hasil pembakaran tidak menyebar ke dapur dan ruangan dalam rumah lainnya.

Hasil penelitian ini ditemukan bahwa lubang pengasapan dapur tidak menunjukkan hubungan yang bermakna terhadap kejadian pneumonia pada balita baik di wilayah pemukiman industri ( $p$-value $=1,000)$ maupun di pemukiman non industri $(p$-value $=0,067)$. Penelitian ini berbanding terbalik dengan penelitian Sunyataningkamso ${ }^{(14)}$ yang menjelaskan bahwa lubang pengasapan dapur merupakan faktor risiko terjadinya pneumonia pada balita karena lubang pengasapan dapur berfungsi sebagai sirkulasi udara saat memasak dan risiko balita pneumonia akan lebih besar jika tidak memiliki lubang pengasapan dapur. Adanya hubungan yang tidak bermakna pada penelitian ini kemungkina disebabkan adanya pemakaian jenis bahan bakar masak yang tidak menimbulkan asap sehingga tidak ditemukan adanya hubungan lubang asap dapur dengan pneumonia pada balita.

e. Kebiasaan Anggota Keluarga yang Merokok

Hasil penelitian ini menunjukkan bahwa kebiasaan anggota keluarga yang merokok merokok tidak ada hubungan yang bermakna terhadap kejadian pneumonia pada balita baik di wilayah pemukiman industri ( $p$-value $=1,000)$ dimana anggota keluarga yang tidak merokok berpeluang 1,115 kali tidak mengalami pneumonia dibandingkan dengan anggota keluarga yang tidak merokok maupun di wilayah pemukiman non industri ( $p$-value $=0,115$ ) dimana anggota keluarga yang tidak merokok berpeluang 3,438 kali tidak mengalami pneumonia. 
Meskipun tidak ditemukannya hubungan antara merokok dengan pneumonia pada penelitian ini, keberadaan perokok dalam rumah tetap perlu diperhatikan karena perokok dan perokok pasif memiliki risiko 2 kali lebih besar mengalami kematian daripada perokok dan 38\% lebih cepat mengalami penyakit. Asap rokok yang berada dalam rumah berhubungan dengan adanya bakteri penyebab penyakit saluran pernapasan seperti Neisseria meningitis, Streptococcus pneumoniae dan Haemophilus influenza. Streptococcus pneumoniae lebih berisiko pada balita yang terpajan asap rokok dibandingkan dengan balita yang tidak terpajan dan semakin meningkat risikonya apabila orangtua atau anggota keluarga yang merokok di dalam ruangan yang sama dengan balita $^{(33)}$. Balita dengan ibu merokok juga memiliki risiko yang besar dibandingkan dengan ibu yang tidak merokok dimana $90 \%$ balita dengan ibu perokok akan menderita pneumonia sedang sampai dengan kronik, sedangkan balita dengan ayah perokok memiliki risiko $74,2 \%$ risiko mengalami pneumonia ${ }^{(34)}$.

Merokok tidak mempunyai hubungan yang bermakna dengan pneumonia disebabkan oleh kemungkinan merokok sebagai faktor risiko memperberat penyakit, sehingga balita yang sudah mempunyai gejala pneumonia, akan semakin memperberat risiko terjadinya pneumonia.

\section{f. Kebiasaan Anggota Keluarga Membakar Sampah}

Pada umumnya rumah tempat tinggal di kota dengan jumlah pertukaran udara yang memadai. Banyak pula dijumpai rumah yang masih melakukan pembakaran sampah sendiri yang asapnya akan mencemari udara dalam rumah. Hasil penelitian Nurjazuli $^{(35)}$ menunjukkan adanya hubungan antara pencemaran dalam rumah tangga dengan kejadian pneumonia pada balita di wilayah Kebumen.

Hasil penelitian ini menunjukkan bahwa keluarga yang membakar sampah di sekitar rumah tidak mempunyai hubungan yang bermakna terhadap terjadinya pneumonia pada balita baik di wilayah pemukiman industri ( $p$-value $=0,594$ ). Tidak adanya hubungan yang bermakna pembakaran sampah dengan pneumonia kemungkinan disebabkan oleh arah dan kecepatan angin yang arahnya tidak mengarah ke rumah subyek penelitian. Arah dan kecepatan angin pada penelitian ini juga menjadi salah satu keterbatasan penelitian karena tidak di ukur dalam penelitian.
Hasil penelitian ini berbanding terbalik dengan penelitian Sumiati ${ }^{(22)}$ yang menyatakan bahwa terdapat hubungan yang bermakna antara polusi rumah tangga (membakar sampah) dengan pneumonia balita dimana rumah tangga yang membakar sampah mempunyai risiko 2,466 kali untuk balita mengalami pneumonia.

\section{KESIMPULAN}

Konsentrasi $\mathrm{PM}_{2,5}$ di wilayah pemukiman industri dan non industri masih dibawah baku mutu dengan konsentrasi terendah sebesar $0,007 \mathrm{mg} / \mathrm{m}^{3}$ berada di wilayah pemukiman industri dan konsentrasi tertinggi sebesar $0,0032 \mathrm{mg} / \mathrm{m}^{3}$ berada di wilayah pemukiman non industri. Pajanan $\mathrm{PM}_{2,5}$ secara statistik tidak mempunyai hubungan bermakna terhadap pneumonia pada balita baik di wilayah pemukiman industri maupun pemukiman non industri.

Konsentrasi $\mathrm{PM}_{2,5}$ dengan penyakit pneumonia pada balita di wilayah pemukiman industri menunjukkan tidak ada hubungan yang bermakna dengan $p$ value 1,000 ( $p$-value $>0,05$. Sedangkan balita di pemukiman non industri diperoleh $p$-value 1,000 ( $p$-value > 0,05) maka dapat disimpulkan tidak hubungan yang bermakna antara pajanan $\mathrm{PM}_{2,5}$ dengan kejadian pneumonia pada balita. Khusus di kawasan pemukiman non industri, pemberian ASI eksklusif dan pememberian vitamin A mempunyai hubungan yang bermakna dengan kejadian pneumonia pada balita.

Balita yang tinggal di kawasan pemukiman industri dengan konsentrasi $\mathrm{PM}_{2,5}$ tinggi mempunyai risiko untuk menderita pneumonia sebesar 0,687 kali dibandingkan balita yang tinggal di pemukiman industri dengan konsentrasi $\mathrm{PM}_{2,5}$ rendah setelah di kontrol oleh pemberian vitamin A, status gizi, dan imunisasi campak. Sedangkan balita yang tinggal di kawasan pemukiman non industri dengan konsentrasi $\mathrm{PM}_{2,5}$ tinggi mempunyai risiko untuk mengalami pneumonia sebesar 1,288 kali dibandingkan dengan balita yang tinggal di konsentrasi $\mathrm{PM}_{2,5}$ rendah setelah di kontrol oleh letak dapur dan ASI eksklusif.

\section{UCAPAN TERIMAKASIH}

Penulis mengucapkan terimakasih kepada Dinas Lingkungan Hidup Kota Padang yang telah membantu dalam pelaksanaan penelitian. 


\section{DAFTAR PUSTAKA}

1. WHO. (2008). World Health Organization. Dipetik Oktober 15, 2016, dari Bulletin of the World Health Organization: Epidemiology and etiology of childhood pneumonia: http://www.who.int/bulletin/volumes/86/5/07 $-048769 / \mathrm{en} /$

2. Kemenerian Kesehatan Republik Indonesia. (2013). Riset Kesehatan Dasar Republik Indonesia Tahun 2007.

3. Dinas Kesehatan Kota Padang. (2015). Profil Kesehatan Kota Padang 2015. Padang: Dinas Kesehatan Kota Padang.

4. Novirsa, Randy. (2012). Analisis Risiko dan Gambaran Spasial Pajanan PM2,5 di Udara Ambien (Outdoor) di Siang hari Terhadap Masyarakat di Kawasan Indusri (Studi Kasus di Kawasan Industri PT Semen Padang Kecamatan Lubuk Kilangan, Padang, Tahun 2012). Skripsi. FKM UI.

5. Getrudis. (2010). Hubungan Antara Kadar Partikulat (PM10) Udara Rumah Tinggal dengan Kejadian ISPA Pada Balita di Sekitar Pabrik Semen PT Indocement. Depok: FKM UI.

6. Rahmawati, Rizki. (2014). Perbandingan Tingkat Risiko Pajanan PM2,5 Udara dalam Rumah pada Balita di Dua Kecamatan (Duren Sawit, Jakarta Timur dan Natar, Lampung Selatan). Depok: FKM UI

7. Rizkianti, A. (2014). Faktor-faktor yang Berhubungan dengan Kejadian Pneumonia pada Balita 10-59 Bulan yang Dirawat Inap di RSUP Persahabatan Jakarta Tahun 2008. Depok: FKM UI.

8. Hartati, S. (2011). Analisis Faktor Risiko yang Berhubungan dengan Kejadian Pneumonia pada Balita di RSUD Pasar Rebo Jakarta. Depok: FIK UI.

9. Sumiati. (2014). Faktor-Faktor yang Berhubungan dengan Kejadian Pneumonia pada Balita pada Enam Puskesmas di Kecamatan Ciracas Kotamadya Jakarta Timur Tahun 2014. Depok: FKM UI.

10. Klemm, R. L., Christian, P. A., Rashid, M., Shamim, A., Katz, J., Sommer, A., et al. (2008). Newborn Vitamin A supplementation Reduced Infant Mortality in Rural Bangladesh. Pediatrics 122, 242 - 250.

11. Zang, L. (2010). Using Charcoal as Base Material Reduces Mosquito Coil Emissions of Toxins. National Institute of Health, 20, 176 $-184$.

12. Liu W., e. a. (2003). Mosquito Coil Emissions anda Health Implications. Environmental Health Perspectives, 111 , 1454 - 1460.

13. Dherani, M. (2008). Indoor Air Pollution drom Unproccessed Solid Fuel Use and Pneumoia Risk in Children Under Five Years: A Systematic Review and Meta-analysis. Bultin of The World Health Organization Vol. 86, 390 - 398.

14. Greenberg D., e. a. (2006). The Contribustion of Smoking an Exposure to Tobacco Smoke to Streptococcus pneumoniae and Haemophilis influenzae Carriage in Children and Their Mother. Clinical Infectious Disease , 897 903.

15. Tiewsoh, K., et al. (2009). Factors Determining the Outcome of Children Hozpitalized with Severe Pneumonia. Biomed Central Paediatric.

16. Nurjazuli, W. (2009). Faktor Risiko Dominan Kejadian Pneumonia pada Balita. FKM Undip. 